\title{
The size and growth potential of the digital economy in ODA-eligible countries
}

George Herbert and Lucas Loudon

01 December 2020

\section{Question}

Provide an overview on:

- The current size of the digital market (however it is defined in available research);

- The countries promoting development of digital business and their approach through Trade Policies or Incentive Frameworks;

- The current and potential size of the market with the UK / China / US / other significant countries

\section{Contents}

1. Summary

2. How is the digital market defined and measured?

3. Why should we care about the digital economy?

4. Size and growth prospects of the digital economy.

5. What are the implications of the digital economy for services trade?

6. What explains variation in the size of the digital economy between regions and countries?

7. What are developing countries doing to promote digital economy growth?

8. References

The K4D helpdesk service provides brief summaries of current research, evidence, and lessons learned. Helpdesk reports are not rigorous or systematic reviews; they are intended to provide an introduction to the most important evidence related to a research question. They draw on a rapid deskbased review of published literature and consultation with subject specialists.

Helpdesk reports are commissioned by the UK Foreign, Commonwealth, and Development Office and other Government departments, but the views and opinions expressed do not necessarily reflect those of FCDO, the UK Government, K4D or any other contributing organisation. For further information, please contact helpdesk@k4d.info. 


\section{Summary}

Estimates of the value of the global digital economy range between around $4.5 \%$ and $\mathbf{2 2 . 5 \%}$ of world GDP, depending on the definition of the digital economy used. The narrowest definition focuses on ICT sector value-added and was stable at around $4.5 \%$ of GDP from 2008-2018 (UNCTAD, 2019a). Higher estimates tend to come from models that include spillover effects of ICT on other parts of the economy; using a methodology of this kind Huawei and Oxford Economics (2017) estimated that the global digital economy was worth $15.5 \%$ of GDP in 2016, whilst Accenture's (Knickrehm et al., 2016) estimate that in 2015 the world's digital economy contributed $22.5 \%$ of global GDP.

The world's digital economy is dominated by two countries, the USA and China. The digital economy is relatively more important in advanced economies than in developing countries. As a result, other developing countries represent a relatively small portion of the digital economy. The USA and China likely accounted for around $44 \%$ of the world's digital economy in 2015 (Knickrehm et al., 2016). Moreover, as UNCTAD (2019a) notes: "these two countries account for 75 per cent of all patents related to blockchain technologies, $50 \%$ of global spending on loT, and more than 75 per cent of the world market for public cloud computing...[and] they account for 90 per cent of the market capitalization value of the world's 70 largest digital platforms." As of 2019 they also account for around $72 \%$ of global e-commerce sales (EMarketer, 2020a). Huawei and Oxford Economics (2017) estimated that the digital economy represented $18.4 \%$ of GDP in advanced economies but just $10 \%$ of GDP in developing countries; this implies that in 2017 developing countries likely contributed less than $27 \%$ of the world's digital economy.

A limitation of this rapid evidence review stems from the lack of consistent methodologies for estimating the size of the digital economy. The OECD is attempting to develop a standard approach to measuring the digital economy across the national accounts of the G20 (OECD, 2020), but this has not yet been finalised. This makes comparing the results of different studies very challenging. The problem is particularly stark in low income countries, where there are frequently huge gaps in the relevant data.

Estimates of ICT sector Gross Value Added (GVA) are only patchily available. Relatively recent estimates of ICT gross value added (GVA) have been produced by the World Bank for nine African countries. Of these the mean contribution of ICT to GDP was $4.5 \%$; for comparison, the figure for the EU as a whole was 3.6\% of GDP in 2017 (Eurostat, 2020). Equivalent estimates appear to be missing for developing countries in other regions.

Estimates of the size of the internet economy conducted by Google suggest that it is worth slightly less than 4\% of GDP in both Southeast Asia and Africa. Research projects conducted by Google found that the internet economy in the six main Southeast Asian economies was worth around 3.7\% of GDP in 2019 (Google \& Temasek, 2019) and that the internet economy in Africa was worth around 3.9\% of GDP there (Google \& IFC, 2020), in both cases with an absolute value of around $\$ 100$ billion. There are no up to date estimates of the size of the internet economy in Latin America, South Asia or China. Castillo's (2013) estimates of the internet economy for key Latin American countries (Argentina: 2-2.2\% of GDP; Brazil: 1.52.2\%; Chile: 1.3\%; Mexico: 1-2.5\%) data from before 2013, whilst McKinsey's estimates for India 
(2.1\% of GDP) date from 2013 (Government of India, 2018). It remains unclear whether a consistent methodology has been utilised across these studies.

Based on other broad definitions, the digital economy in Latin America appears relatively large, but to be growing relatively slowly. Accenture conducted estimates for selected countries for 2015 based on a broad definition of the digital economy. This research indicates that the contribution of the digital economy to GDP in Latin America's four largest economies was substantially higher than in China (averaging 19\% compared to $11 \%$ ), but that China's digital economy was growing at around double the speed (around 6.7\% compared to $3.7 \%$ ).

The mobile economy appears relatively more important to Sub-Saharan Africa than in the Asia Pacific region or Latin America. Research by telecommunications industry body GSMA (2020a; 2020b) suggests that the 'mobile ecosystem' in the Asia Pacific dwarfs that in Africa or Latin America, but that its relative contribution to GDP in Africa is almost double that in the Asia Pacific or Latin America (see Table 1). This likely reflects the important role played by mobile money in the African economy (GSMA, 2019b).

Table 1: size of the 'mobile ecosystem' in Africa, Asia Pacific and Latin America.

\begin{tabular}{lll}
\hline Region & GVA & Contribution to GDP \\
\hline Africa & $\$ 155$ billion & $9 \%$ \\
Asia Pacific & $\$ 1.6$ trillion & $5 \%$ \\
Latin America & $\$ 216$ billion & $5 \%$ \\
\hline
\end{tabular}

Source: GSMA (2019; 2020a; 2020b). (c) GSM Association 1999 - 2019

The importance of the e-commerce sector varies hugely between regions. In 2020 ecommerce may account for $41 \%$ of China's retail (eMarketer, 2020b). In contrast, it represented just 5\% of India's retail sector in 2018 (Government of India, 2018) and possibly less than $1 \%$ of the Philippines' (World Bank, 2020). In Africa data availability is patchy, but represents a small share of retail almost everywhere - even in South Africa, one of the region's most technologically advanced countries - e-commerce represented just 1.4\% of retail sales in 2018 (Goldstruck et al., 2018). In Latin America, in 2019, e-commerce represented 4\% of sales (eMarketer, 2020c).

However, the e-commerce sector is growing rapidly almost everywhere and this looks set to continue. In Southeast Asia the e-commerce sector grew seven-fold between 2015 and 2019; it at least doubled in every one of the six countries in the region, whilst in Indonesia, it grew twelve-fold to $\$ 21$ billion. China's e-commerce sector has been growing incredibly rapidly, and even accounting for COVID-19 it is expected to grow $16 \%$ in 2020. The share of e-commerce in retail sales in Latin America more than doubled from 2015-2019 (eMarketer, 2020c), and the sector is expected to grow $19 \%$ in 2020. In the Middle East and North Africa (MENA) e-commerce penetration almost doubled from 2015-2019 (Bain, and Co., 2019).

Businesses utilising new digital technology are already revolutionising the services sector in many developing countries. China's Didi ridesharing app alone has at least four million drivers who are active on a monthly basis (Leverenz et al., 2019), whilst India's Ola has 2.5 million drivers (Singh, 2020), whilst Uber may have a similar number of drivers in India as 
Ola. Such platforms are at an earlier stage in Africa, but there is evidence for strong growth (Genesis Analytics, 2020) and it seems likely that this will accelerate in the next few years as internet penetration improves and mobile data becomes cheaper.

Financial technology (Fintech) activities have been growing rapidly in developing countries - they both form part of the digital economy itself and facilitate the growth of the digital economy. In 2019 there were 372 million active mobile money accounts globally, with most accounts coming from developing countries, and the African market dominating the sector. Africa was the world's leading region for mobile money. There were over 181 million active mobile money accounts there, compared to 91 million in South Asia, 60 million in Southeast Asia, 19 million in MENA and 13 million in Latin America (GSMA, 2019b).

The key factors impeding the development of the digital economy in developing countries are: (1) weak digital infrastructure; and (2) a lack of digital skills amongst workers and consumers. This is particularly the case in Africa and amongst the world's least developed countries, who lag far behind both advanced economies and most middle-income countries. In much of Africa and parts of South Asia over three-quarters of people are still not internet users. The cost of access to the internet is generally higher in Africa than in advanced economies and the reliability and speed of internet connections are generally much worse (ITU \& UNESCO, 2020). The proportion of people lacking basic digital skills is much higher in developing countries than the advanced economies, and higher still in the least developed countries (ITU \& UNESCO, 2020), an issue sometimes compounded by literacy issues. High-level digital skills, such as coding, are also (unsurprisingly) much rarer in the least developed countries. Efforts to ensure widespread basic digital skills and to build a cadre of highly skilled workers will be required if developing countries are to harness the full potential of their digital economies.

\section{Broader business climate issues can also undermine the development of the digital economy in developing countries. This includes:}

- Bureaucratic regulations that make it difficult for start-ups to set-up and begin operations

- Challenges for start-ups securing financing to set-up and scale-up

- Restrictions on FDI or a poor investment climate, that prevents the diffusion of digital know-how to developing counties

- Logistics sector weaknesses that impede the development of e-commerce specifically.

Developing countries are undertaking a range of measures to address these weaknesses and harness the potential of the digital economy. Many developing countries now have strategies focused on the development of their digital economies, whilst 174 countries have strategies to improve broadband quality and access (ITU \& UNESCO, 2020). Fibre-optic networks have expanded hugely across developing countries in the past decade, whilst governments have also been targeting improvements in their $4 \mathrm{G}$ mobile networks. and other the rate of expansion in. Many developing countries have recognised the importance of building digital skills, and are increasing investment in technology-orientated subjects at school and university-level. Many middle-income countries have some form of a system of subsidies for private-sector R\&D, much of which likely flow to digitally orientated businesses. Some larger or more prosperous middle-income countries (such as India and Malaysia) appear to have relatively well-developed systems of grants and other incentives for entrepreneurs starting technologyorientated businesses, but this appears rare in Africa. 
This rapid evidence review draws on a variety of sources, including reports by international organisations (such as the World Bank and OECD), grey literature produced by think tanks and the private sector, and peer reviewed academic papers. A high proportion of estimates of the size of the digital economy come from research conducted by or for corporations and industry bodies, such as Google and the GSMA (which represents the telecommunications industry). Their research may be influenced by their business interests, the methodologies and data sources they utilise are often opaque, and the information required to critically assess findings is sometimes missing. Given this, the estimates presented in this review are best seen as ballpark figures rather than precise measurements.

\section{How is the digital market defined and measured?}

The concept of the Digital Economy dates back to the 1990s when policymakers and academics began to recognise the potential economic impact of the internet on the real economy (Barefoot et al., 2018). Over time definitions of the digital economy have evolved and proliferated. There remains no universally accepted definition of the term, though the OECD is working to create a harmonised approach to measurement for the G20 (OECD, 2020).

Various approaches to measuring the digital economy can be found in the literature:

- The 'narrow' approach takes it as synonymous with the ICT sector (Sedik et al., 2019).

- The iGDP approach takes the digital economy to represent the contribution of the internet to GDP (Manyika et al., 2013; Castillo, 2013), often focusing on a number of key online sectors (e.g. online travel, online media, ride-hailing, e-commerce, and digital financial services). A somewhat similar approach is taken to measurement of the digital economy is taken by Barefoot et al. (2018), who include ICT value-added plus value-added from "internet-enabled" business (e.g. e-commerce; ride-hailing apps; digital media).

- 'Broad' approaches (Sedik, et al., 2019), tend to include both the direct value-added of the ICT sector and the contribution of spillover effects from digital technology on the rest of the economy. A key problem when using broad definitions relates to how much of the value-added of digitally enabled or enhanced transactions or businesses should be attributed to the digital economy. There is no single way of determining this, meaning that it is challenging to compare studies by different researchers even where both use similarsounding 'broad' definitions of the digital economy. Examples include the estimates derived from models created by Oxford Economics in partnership with Accenture (Knickrehm et al., 2016) and Huawei (Huawei and Oxford Economics, 2017).

- The 'mobile ecosystem', as championed by GSMA (the telecommunications industry body). This is in some ways more restricted than the digital economy, in that it focuses only on mobile telephony and not computer-based technology. However, GSMA adopts a broad approach to assessing the value-added of the mobile ecosystem, with their estimates being dominated by the indirect improvements in productivity they estimate are achieved through the use of mobile technology. This is referred to several times in the report reflecting the central role of the mobile sector in the digital economy in most developing countries, and the fact that they provide data for multiple regions, which is useful when making comparisons. 
None of these approaches is definitively better than the other, and all have their use. This reflects the different reasons why the digital economy is of interest, and the need to understand different aspects of how technology is affecting the economy and society. In line with this, Armstrong (2020) argues that the digital economy is best understood not as a homogenous entity, but as a system with several layers:

- The 'digital core', including "providers of physical technologies like semiconductors and processors, the devices they enable like computers and smartphones, the software and algorithms which run on them, and the enabling infrastructure these devices use like the internet and telecoms networks"

- 'Digital providers' that use digital technology to "provide digital products and services like mobile payments, e-commerce platforms or machine learning solutions"

- 'Digital applications', which includes businesses using digital technology and the services of digital providers "to transform the way they go about their business." This

Digital infrastructure and economic growth

Econometric evidence suggests that improved telecommunications infrastructure is important for economic growth. World Bank (2009) analysis using data from 120 countries suggested a 10-percentage point increase in broadband penetration results in a 1.3 percentage point increase in GDP. Modelling by the International Telecommunication Union (ITU, 2019) using panel data for Latin America and the Caribbean for the period 2005-2017 suggests that a 10-percentage point increase in fixed broadband penetration yielded a $1.9 \%$ increase in GDP, whilst in Africa research suggests it may yield a 2.5 percentage point increase in GDP (Google and IFC, a member of the World Bank Group, 2020). includes applications like virtual banks, digital media, and e-government services.

\section{Why should we care about the digital economy?}

Growth of the digital economy is important first and foremost simply because it is growth, offering a viable route to improved living standards for those living in low income and middle-income countries. Moreover, they are particularly important for labour productivity growth, which is key to driving increased wages in the long-term: in the US $86 \%$ of labour productivity growth over the period 2013-2017 came from "digital-producing industries" which only represented $8.2 \%$ of GDP (van Ark \& de Vries, 2019).

The fact that the digital economy is worth studying separately from the rest of the economy also reflects the unique opportunities and challenges it poses. The rise of the digital economy looks set to be socially disruptive. Digital economic growth has led (and will continue to lead) to the creation of whole new professions, value chains and business models, to undermine the viability of old ways of working and to threaten livelihoods for those not wellpositioned to take advantage of new opportunities. These costs and benefits need to be assessed and considered.

Governments will need to take action to help the digital economy in their countries achieve its full potential and to make sure they can cope with the changes that growth will create. To help the digital economy flourish governments will need to consider changes to regulatory regimes, as well as investments in supporting ICT infrastructure and in education and 
skills development for their current and future workforce. They will also need to consider (at the national and international level) the implications the shift towards a digital economy has for the tax system, including the need to find effective ways to tax digital-only value creating activity, and to ensure fair taxation of multinational digital businesses.

The digital economy has already begun to revolutionise service sector work in developed countries and this will increasingly be felt in developing countries. Global platforms such as Uber have begun to achieve strong market penetration in developing countries and have been joined by numerous home-grown firms attempting to fill similar roles. For example, in South Africa, there are more than 45 home-grown digital platforms operating in the services sector (Genesis Analytics, 2020). China's Didi ridesharing app alone has 4-5 million drivers who are active on a monthly basis (Leverenz et al., 2019), whilst India's Ola has 2.5 million drivers (Singh, 2020). The development of these services is at an earlier stage in most of Africa, with just 20,000 ride-sharing drivers in South Africa and. However, such platforms are growing and seem likely to take off in the coming years.

Financial technology (Fintech) activities have been growing rapidly in developing countries and are helping to overcome weaknesses in the formal banking sector in many countries. Fintech is both part of the digital economy itself and facilitates the growth of the digital economy. Mobile money services enabled by digital technology represent a particularly important means to improve financial inclusion. In 2019372 million active mobile money accounts globally, with most accounts coming from developing countries, and Africa dominating the sector. Africa was the world's leading region for mobile money, reflecting the huge number of unbanked individuals there. There were over 181 million active mobile money accounts there, compared to 91 million in South Asia, 60 million in Southeast Asia, 19 million in MENA and 13 million in Latin America (GSMA, 2019b).

Digital platforms partly facilitate transactions that would already have happened, but they also make new markets by bringing together customers and suppliers who would never otherwise have been able to connect, creating new job opportunities. The growth of ridehailing in South Africa has doubled the number of taxi service jobs in the country (Genesis Analytics, 2020). Similarly, AirBnB alone has created the equivalent of 22,000 income opportunities in South Africa, whilst over 3,000 cleaning jobs were created by on-demand cleaning apps in one year alone. In Indonesia, around 30\% of online commerce spending is new consumption, capturing previously untapped needs (Sedik et al., 2019). E-commerce also appears to have a significantly positive knock-on effect on total factor productivity (Sedik et al., 2019).

The COVID-19 pandemic has also highlighted the important role the digital economy can play in promoting economic resilience to certain kinds of shock. During COVID-19 the digital economy has allowed businesses to continue operating that would otherwise have been forced to close entirely (World Bank, 2020). Whilst there is a lack of good research to date examining the relationship between the development of the digital economy and economic resilience in the face of COVID-19, it seems likely that such a link will be found once the relevant data becomes available. 


\section{Size and growth prospects of the digital economy.}

\section{Global:}

UNCTAD (2019a) state that the digital economy is likely in the range $4.5-15.5 \%$ of global GDP depending on the definition of digital economy used. Using a 'broad' definition of the digital economy - based on an indirect model-based approach - Knickrehm et al. (2016) estimate that in 2015 the global size of the digital economy was around $\$ 16.2$ trillion, or $22.5 \%$ of world GDP. In contrast, Huawei and Oxford Economics (2017) - also using a somewhat similar but distinct 'broad' definition - estimate the global digital economy in 2016 was worth $\$ 11.5$ trillion or $15.5 \%$ of global GDP.

The digital economy is relatively less important in developing countries than in advanced economies, but this is changing. Huawei and Oxford Economics (2017) estimate that the digital economy is worth around $18 \%$ of GDP in advanced economies, but just $10 \%$ of GDP in developing countries. Estimates indicate that the digital economy will grow very rapidly in the next few years in developing countries, but the pace of change varies substantially between and within regions.

The global digital economy has been growing substantially faster than the non-digital economy. Digital platform companies have been growing at a particularly rapid rate in recent years. Between 2015 and 2017 the combined value of digital platform companies with a market capitalization above $\$ 100$ million grew by 67\% (UNCTAD, 2019a). Oxford Economics and Huawei (2017) estimate that the global digital economy grew 2.5 times faster than the overall GDP from 2000-2015. Across OECD countries economic sectors with high levels of ICT factor intensity have grown 1.7 times faster than the average growth rate of the economy (OECD, 2015).

The COVID-19 pandemic will likely significantly reduce global GDP, but whilst it may reduce the pace of growth of the digital economy it will likely increase its relative importance. There is evidence that - in both developing countries and advanced economies the growth of e-commerce will slow in 2020, but that it will continue to grow whilst the rest of the retail sector shrinks (eMarketer.com, 2020). Moreover, lockdowns and social distancing have encouraged technological adoption and adaptation worldwide, including in developing countries (e.g. the Philippines - World Bank, 2020), suggesting that COVID-19 may - in the long-term work to increase the pace at which the global economy becomes digitalised.

\section{Regional estimates:}

\section{The USA and Europe}

Whilst the digital economy in advanced economies is not the focus of this review, some of the best available data relate to these economies, providing a useful benchmark when estimating the size of the digital economy in ODA-eligible countries.

The US Bureau of Economic Affairs (BEA) (Barefoot et al., 2018) estimates that the US digital economy (defined as ICT plus online business) was valued at $\$ 1,209$ billion in 2016 , or $6.5 \%$ of GDP and accounted for $3.9 \%$ of total employment. Looking in more detail at the components of the digital economy hardware and e-commerce and digital media each accounted for around $11 \%$ of the digital economy in 2016 , but had the highest growth rates across all digital sub-sectors over the period $2006-2016$, averaging around $8 \%$ and $12 \%$ respectively, compared 
to the less than $5 \%$ annual growth achieved by the support serves, software and telecommunications sub-sectors.

\begin{abstract}
An updated set of estimates for the USA have subsequently been produced by the BEA (Nicholson, 2020), utilising a broader methodology for calculating he size of the digital economy. Whilst their 2018 estimates only included goods and services that were "primarily digital", the 2020 estimates also include the in-scope portion of goods and services deemed "partially digital." This expanded the amount of retail and wholesale e-commerce items included in estimates. Based on this system the size of the digital economy in the US in 2016 was around $36 \%$ larger than previously estimated at $\$ 1,600$ billion or $8.9 \%$ of GDP and the annual growth rate of the digital economy was revised upwards to $6.8 \%$. Based on the revised estimates the digital economy was responsible for 8.8 million jobs in 2018 or $5.7 \%$ of employment.

Extrapolating the revised figures and growth rates, the digital economy would be forecast to reach $20 \%$ of GDP by 2033,11 years earlier than previously estimated. BEA's new estimation method led to a large increase in the share of e-commerce in the digital economy compared to their previous estimates - accounting for $25 \%$ of the digital economy in 2018.
\end{abstract}

In the US the growth of the digital economy is substantially outstripping GDP growth. The US Bureau of Economic Affairs (BEA) (Barefoot et al., 2018) estimates that from 2006 to 2016 the US real economy overall grew at a rate of just $1.5 \%$ a year, whilst the digital economy grew at a rate of $5.6 \%$ a year. Similarly, employment in the digital economy grew $3.7 \%$ a year in the digital economy, compared to just $1.7 \%$ a year for the economy overall. Projecting out these trends the digital economy would be forecast to be responsible for $10 \%$ of US GDP by 2026 and $20 \%$ by 2044 .

The digital economy is likely slightly less important in Europe than in the USA as a share of economic activity. For Europe, official statistics show that the EU's ICT sector contributed around $\$ 475$ billion of value-added in 2017, with the sector employing 5.4 million people (Eurostat, 2020a). The direct value added stemming from the ICT sector has risen only risen slightly: from accounting for $3.48 \%$ of GDP in 2012 by 2017 it accounted for $3.59 \%$ of GDP (Eurostat, 2020a). Alternative methodologies vary in their estimation of the size of the digital economy in Europe and the USA. Accenture's estimate (Knickrehm, et al., 2016), based on a very broad definition, suggests the digital economy contributed $32.5 \%$ of US GDP in 2015, around $30 \%$ of GDP in the UK, and around $25 \%$ of GDP in France and Germany.

\title{
Asia
}

The digital economy is already an important contributor to Asia's regional GDP. GSMA, which represents the interests of the mobile phone industry globally, estimates that the mobile ecosystem (mobile phones and related services) contributed \$1.6 trillion of GVA across the Asia Pacific region in 2019, around 5.3\% of GDP (GSMA, 2020a). This reflects $\$ 3.6$ billion in direct contribution and $\$ 13.1$ billion in the form of indirect contributions and productivity increases enabled by mobile technology.

This in large part reflects the importance of the digital economy in the region's two most important economies, China and India. Accenture suggests that the digital economy contributed around 11\% of China's GDP in 2016 (Knickrehm et al., 2016), around a third of the share of the digital economy in the UK and USA. IMF estimates (using a different methodology) put it as high as 30\% in 2019 (Zhang et al. 2019). Research by McKinsey and the Government of India (Kaka et al., 2019; Government of India, 2018), using similar definitions of the digital 
economy, found that the digital economy in India was worth around $\$ 170-200$ billion of GVA in 2017-18, or 7-8\% of GDP; this comprised: (1) $\$ 115$ billion from IT and business process management; (2) $\$ 45$ billion from digital communication services; and (3) $\$ 10$ billion from electronics manufacturing.

The digital economy also appears to be important in most Southeast Asia and South Asia countries but is heavily concentrated in major metropolitan centres. e-Conomy - a research collaboration between Google, Temasek and Bain and Co. - estimates that in 2019 southeast Asia's "internet economy" was valued at $\$ 100$ billion, or around 3.7\% of GDP (Google, Temasek and Bain, 2019). GSMA data for Bangladesh and Pakistan confirm that the digital economy is also important in South Asia (see Table 2, below). However, it is important to note that within Asian countries the importance of the digital economy tends to be highly concentrated on major urban centres. $50 \%$ of the Southeast Asian region's internet economy is located in seven Metropolitan areas which account for just $15 \%$ of the region's population.

Table 2: Mobile ecosystem economic contribution in South Asia.

\begin{tabular}{lllll}
\hline & $\begin{array}{l}\text { GVA from } \\
\text { the mobile } \\
\text { ecosystem } \\
(\$)\end{array}$ & $\begin{array}{l}\text { Contribution } \\
\text { to GDP }(\%)\end{array}$ & $\begin{array}{l}\text { Jobs } \\
\text { contributed by } \\
\text { the mobile } \\
\text { ecosystem }\end{array}$ & Year \\
\hline India & \$140 billion & $6.5 \%$ & 4 million & 2015 \\
Bangladesh & \$13 billion & $6.2 \%$ & 760,000 & 2015 \\
Pakistan & \$16.7 billion & $5.4 \%$ & 450,000 & 2018 \\
\hline
\end{tabular}

Source: GSMA (2020a) @ GSM Association 1999 - 2019; Robinson (2020); Rogers (2018)

The digital economy has been growing rapidly in Asia in recent years, partly driven by a huge expansion in internet access in many countries. Recent years have been characterised by increasing internet availability, faster speeds and lower prices in many Asian countries; in India, for example, data usage quadrupled from 2016-2017 as mobile data prices dropped rapidly (Kaka, et al., 2019). Technological adoption and innovation accounted for $28 \%$ of GDP growth in Asia from 1995-2016 (Sedik et al., 2019), reaching as high as $49 \%$ of GDP growth for Thailand. As can be seen from Table 3, below, this high rate of digital economic growth in has been sustained for the six Southeast Asian nations, with iGDP as a share of GDP more than almost tripling between 2015 and 2019 (Google, et al., 2019).

The development of the digital economy in the Philippines

Using a methodology similar to that used by the BEA for the USA, the World Bank (2020) estimates that the Philippines digital economy grew $12 \%$ per annum between 2012 and 2018, with ecommerce growing particularly quickly at around $25 \%$ per annum.

Forecasts, made prior to the COVID-19 pandemic anticipated this continuing into the 2020s, with iGDP as a percent of GDP expected to more than double from $2.1 \%$ in 2019 to $5.3 \%$ in 2025 (Google \& Temasek, 2019). 
Table 3: iGDP in southeast Asia.

\begin{tabular}{llll}
\hline Country & iGDP (\$), 2019 & $\begin{array}{l}\text { iGDP annual growth } \\
\text { rate (2015-2019) }\end{array}$ & iGDP (\%GDP), 2019 \\
\hline Indonesia & $\$ 40$ billion & $49 \%$ & $3.5 \%$ \\
\hline Thailand & $\$ 17$ billion & $\sim 29 \%$ & $3.1 \%$ \\
\hline Malaysia & $\$ 11$ billion & $\sim 21 \%$ & $3.0 \%$ \\
\hline The Philippines & $\$ 8$ billion & $\sim 31 \%$ & $2.1 \%$ \\
\hline Singapore & $\$ 12$ billion & $\sim 18 \%$ & $3.2 \%$ \\
\hline Vietnam & $\$ 12$ billion & $38 \%$ & $5 \%$ \\
\hline
\end{tabular}

Source : Google \& Temasek, 2019, p.32

Forecasts suggest that Asia's digital economy will continue to outstrip the growth of the rest of the economy. On current trends, digital innovation and adoption could account for $36 \%$ of Asia's economic growth over the next 15 years (Sedik et al., 2017), whilst forecasts from Google et al. (2019) suggest that Southeast Asia's internet economy could triple between 2019 and 2025 to reach $\$ 300$ billion of Gross Marginal Value (GMV). Under a 'business as usual path' path for the development of the digital economy, the Government of India anticipates the digital economy growing to $\$ 500-600$ billion by 2025 , but suggests that with "decisive, significant and speedy action" this could rise to $\$ 800$ billion to $\$ 1$ trillion of GVA (18-23\% of GDP). ${ }^{1}$

Digital growth offers the potential to create a huge number of new jobs, but also to destroy many existing ones. McKinsey forecasts that the growth of the digital economy in India may create 65 million new jobs by 2025, but also destroy 20 million existing jobs (Kaka, et al., 2019), whilst the Government of India (2018) suggests that 40-45 million workers may require retraining in light of the changes wrought by the expansion of the digital economy.

The Asian e-commerce sector is the most important in the world, but take-up varies a lot across the region. In 2020 Asia-Pacific is expected to account for $\$ 2.45$ trillion of e-commerce sales, almost $63 \%$ of global e-commerce (Emarketer.com, 2020). In 2017 China alone accounted for $40 \%$ of global e-commerce (Marinova, 2017) in 2017, double that accounted for by the USA. Whilst e-commerce sales accounted for around 8\% of retail sales in 2016 in North America and Europe, in Asia-Pacific, they accounted for almost $12 \%$ of sales (Sedik et al., 2019). However, the take-up of e-commerce varies a lot across the region. In 2020, there are expected to be over

\footnotetext{
${ }^{1}$ McKinsey, who partnered with the Indian Government for the research quoted above, provide an even lower projection than the Government of India's business as usual projection; they forecast that India's digital economy will grow faster than GDP, rising to \$355-435 billion GVA (8-10\% of GDP) by 2025 (Kaka et al., 2019). This difference appears to reflect the fact that the Government of India's estimates include not just growth in the six existing digital ecosystems considered by McKinsey (within which most of the growth comes from increased GVA in electronics manufacturing and Information Technology Business Process Management (IT-BPM)), but also the extension of the digital economy into "new digital ecosystems" (e.g. agriculture, education, financial services, energy, healthcare and logistics).
} 
$\$ 2$ trillion of Business-to-Consumer (B2C) e-commerce sales in China, representing around 41\% of China's retail sector (EMarketer, 2020). By contrast, India's $\$ 20$ billion of retail e-commerce sales, generating around $\$ 3$ billion of GVA or $0.08 \%$ of GDP, represented just $5 \%$ of the country's total retail sales in 2018 (Government of India, 2018). In the Philippines e-commerce sales made up just $0.5 \%$ of retail sales in 2019 (World Bank, 2020). Whilst $19 \%$ of the population of Malaysia bought a product online in 2017, the figure was just $5 \%$ for Thailand and $1 \%$ for Bangladesh (UNCTAD, 2019b).

\section{The e-commerce sector in Asia has been growing very rapidly and looks set to prove} relatively resilient in the face of COVID-19 pandemic. Between 2013 and 2017 India's ecommerce users rose from 40 million to 177 million people (Government of India, 2018).

Between 2015 and 2019 e-commerce sales in the six largest South-East Asian economies grew seven-fold, with the sector at least doubling in each country (see Table 4). Pre-COVID-19 projections suggested this high rate of growth would continue through to 2025 , by which time ecommerce sales would almost have quadrupled again. Industry experts appear confident that the sector will continue to grow in 2020 despite COVID-19, albeit at a reduced rate. Despite Emarketer.com (2020) forecasting that 2020 will be the first year on record in which China's retail sector shrinks, China's e-commerce sector is forecast to grow $16 \%$, albeit almost eight percentage points less than forecast prior to the pandemic.

Table 4: Value of e-commerce sales in South-East Asia (\$, billions).

\begin{tabular}{llll}
\hline Country & $\mathbf{2 0 1 5}$ & $\mathbf{2 0 1 9}$ & $\mathbf{2 0 2 5}$ (forecast) \\
\hline Indonesia & 1.7 & 21 & 82 \\
\hline Thailand & 0.9 & 5 & 18 \\
\hline Malaysia & 1 & 3 & 11 \\
\hline The Philippines & 0.5 & 3 & 12 \\
\hline Singapore & 1 & 2 & 7 \\
\hline Vietnam & 0.4 & 5 & 23 \\
\hline Regional Total & 5.5 & 39 & 153 \\
\hline
\end{tabular}

Source: Google \& Temasek, 2019.

Fintech has been growing rapidly across the Asia Pacific. Growth has been strong in both upper-middle-income countries such as Malaysia and Thailand and in lower-middle-income countries like Mongolia and Bangladesh (Sedik et al., 2019). In addition, there is some evidence for Fintech convergence, with countries with lower baseline levels of digital payments in 2014 growing at a faster rate in subsequent years (Sedik et al., 2019). By 2025 Digital Payments are expected to account for $\$ 1$ trillion of payments in Southeast Asia, accounting for almost one in every two dollars spent in the region (Google \& Temasek, 2019). 


\section{Latin America}

Research from Accenture indicates that in 2016 the contribution of the ICT sector to GDP ranged from $16 \%$ to $22 \%$ across Latin America's four largest economies (see Figure 1, below). This is higher than estimates for most economies in Asia, including India and China. It is also substantially higher Castillo's (2013) estimates for the contribution of the 'internet economy' to GDP in the same four countries in 2013 (Argentina: 2-2.2\%; Brazil: 1.5-2.2\%; Chile: 1.3\%; Mexico: $1-2.5 \%$ ), likely reflecting a combination of a different methodology and the development of the digital economy in the region.

See: Figure 1: Contribution of ICT GVA to GDP in four Latin American countries, Source: Accenture, 2018, p.5, https://www.accenture.com/t00010101t000000z_w_/cles/_acnmedia/pdf-71/accenture-digital-index-chile.pdf

GSMA (2019a) estimate that in 2018 the mobile ecosystem contributed around \$261 billion of GVA across Latin America, mainly by supporting enhanced productivity across the whole economy. This represents $5 \%$ of regional GDP, a similar rate to that found by GSMA for the Asia Pacific. This is assessed to have contributed around 1.7 million jobs either directly or indirectly.

Pre-COVID-19 forecasts anticipated healthy growth of the digital economy in Latin America in the coming years. Accenture (2018) forecasts that from 2016-2021 across Latin America's four biggest economies the GVA of the digital economy to GDP will rise by between a low of $3.2 \%$ per annum in Mexico and a high of $4.4 \%$ per annum in Argentina. GSMA forecast that the GVA of the mobile ecosystem in Latin America will grow 15\% between 2019 and 2023, to reach $\$ 300$ billion of GVA.

The e-commerce sector in Latin America remains relatively under-developed but is growing steadily. In 2019181 million Latin American consumers bought a product online, around $29 \%$ of the region's total population, with an increase of around 10 million buyers expected in 2020. The e-commerce sector in Latin America accounted for less than $2 \%$ of sales in the mid-2010s (Sedik et al., 2016), but by 2019 had risen to $4.4 \%$ of retail sales ( $\$ 70$ billion) (eMarketer.com, 2020). eMarketer (2020) (post-COVID-19) forecast is that this will rise by more than $19 \%$ to $\$ 83.6$ billion in 2020 (5.6\% of retail sales), with slowing but still double-digit growth in coming years expected to take sales to $\$ 116$ billion by 2023 (7.1\% of retail sales).

\section{Middle East and North Africa}

The digital economy of the MENA region is relatively under-developed. McKinsey research indicates that around 2015 the digital economy accounted for $\$ 69.7$ billion of GVA in the Middle East region ${ }^{2}$ or $4.1 \%$ of GDP (Elmasry, et al., 2016). However, this varied significantly between countries, from as high as $8 \%$ for Bahrain to as low as $0.4 \%$ for Qatar (see Figure 2, below). The share of the Middle Eastern workforce employed in digital jobs is also low at just $1.7 \%$, around half the level in Europe and the USA. The data for the Maghreb appears broadly similar: the ICT sector in Morocco generated 5-6\% of GDP in 2019 (Oxford Business Group, 2020) and 4.3\% of GDP in Tunisia in 2017 (World Bank, 2020d).

\footnotetext{
${ }^{2}$ Bahrain, Egypt, Jordan, Kuwait, Lebanon, Oman, Qatar, Saudi Arabia, and the United Arab Emirates
} 
See: Figure 2: Digital GVA in the Middle East, 2015, Source: Elmasry, et al., 2016., p.25, https://www.mckinsey.com/ /media/mckinsey/featured\%20insights/middle\%20east\%20and\%20a frica/digital\%20middle\%20east\%20transforming\%20the\%20region\%20into\%20a\%20leading\%20 digital\%20economy/digital-middle-east-final-updated.pdf

The Middle East and North Africa (MENA) region's e-commerce market is small, but growing. The Middle East and North Africa MENA e-commerce market was valued at $\$ 8.3$ billion in 2017, having been growing at a rate of around $25 \%$ per annum in previous years (Bain, and Co., 2019). This equates to around $1.9 \%$ of total retail sales, up from around 1\% in 2015 (Elmastry et al., 2016) which is around eight times less penetration than e-commerce enjoyed in 2017 in the UK (ONS, 2020). The mean e-commerce spending per internet user was just $\$ 100$ annually (ICANN, 2017). Few Small and Medium Sized Enterprises (SMEs) in the region make use of the internet: only $18 \%$ of SMEs in the UAE, $15 \%$ of SMEs in Saudi Arabia, $7 \%$ of SMEs in Egypt and 37\% of SMEs in Turkey have an online presence (Elmasry et al., 2016). The development of e-commerce also varies a huge amount across the MENA region. The GCC accounts for around $44 \%$ of the MENA region's GDP but $72 \%$ of the region's e-commerce sales (Bain \& Co., 2019).

\section{Africa}

The "internet economy" in Africa represents a similar proportion of the region's GDP as in Southeast Asia. Google and the IFC (2020), quoting a recent forecast by Accenture, estimate that the GVA of Africa's "internet economy" (iGDP) was $\$ 100$ billion in 2019 , or $3.9 \%$ of GDP. The contribution of iGDP to the economy varies substantially between African economies (see Error! Reference source not found.3). Kenya is the highest performer with iGDP of $7.7 \%$ of total GDP, but the figure is just $1.27 \%$ in Ethiopia and is likely even lower in many of Africa's smaller economies (for which disaggregated data is not provided). 
Figure 3: iGDP forecasts for Africa.

\begin{tabular}{|c|c|c|c|c|c|c|}
\hline Country & 2020 (\$B) & $2020(\%)$ & 2025 (SB) & $2025(\%)$ & 2050 (SB) & $2050(\%)$ \\
\hline Kenya & 7.42 & $7.70 \%$ & 12.84 & $9.24 \%$ & 51.07 & $15.17 \%$ \\
\hline Morocco & 7.80 & $6.82 \%$ & 12.09 & $7.84 \%$ & 48.06 & $12.88 \%$ \\
\hline South Africa & 21.55 & $6.51 \%$ & 31.45 & $7.86 \%$ & 125.08 & $12.92 \%$ \\
\hline Senegal & 1.51 & $6.22 \%$ & 2.92 & $7.11 \%$ & 11.61 & $11.68 \%$ \\
\hline Nigeria & 24.59 & $5.68 \%$ & 36.53 & $6.86 \%$ & 145.28 & $11.27 \%$ \\
\hline Algeria & 9.02 & $5.60 \%$ & 11.92 & $6.16 \%$ & 47.39 & $10.12 \%$ \\
\hline Cameroon & 2.06 & $5.39 \%$ & 3.27 & $6.19 \%$ & 13.00 & $10.16 \%$ \\
\hline Côte d'Ivoire & 3.18 & $5.27 \%$ & 5.53 & $6.04 \%$ & 21.98 & $9.92 \%$ \\
\hline Egypt & 15.41 & $4.98 \%$ & 25.97 & $5.99 \%$ & 103.29 & $9.83 \%$ \\
\hline Rwanda & 0.52 & $4.98 \%$ & 0.97 & $5.96 \%$ & 3.85 & $9.79 \%$ \\
\hline Ghana & 3.01 & $4.42 \%$ & 5.01 & $5.31 \%$ & 19.94 & $8.73 \%$ \\
\hline Tanzania & 2.57 & $3.98 \%$ & 4.28 & $4.57 \%$ & 17.03 & $7.50 \%$ \\
\hline Uganda & 1.36 & $3.82 \%$ & 2.26 & $4.18 \%$ & 8.97 & $6.87 \%$ \\
\hline Mozambique & 0.37 & $2.45 \%$ & 0.67 & $2.81 \%$ & 2.65 & $4.62 \%$ \\
\hline Angola & 2.02 & $2.17 \%$ & 2.88 & $2.38 \%$ & 11.44 & $3.91 \%$ \\
\hline Ethiopia & 1.26 & $1.27 \%$ & 2.02 & $1.39 \%$ & 8.03 & $2.28 \%$ \\
\hline Rest of Africa & 11.62 & $1.96 \%$ & 18.55 & $2.16 \%$ & 73.76 & $3.54 \%$ \\
\hline Total & $\$ 115$ & $4.5 \%$ & $\$ 180$ & $5.2 \%$ & $\$ 712$ & $8.5 \%$ \\
\hline
\end{tabular}

Source: Google and IFC, a member of the World Bank Group (2020), p.16, using data from a 2020 report by Accenture

This is broadly consistent with other measures of the development of Africa's digital economy. Data from GSMA is broadly similar, indicating that the GVA contributed by SubSaharan Africa's 'mobile ecosystem' was around $\$ 155$ billion in 2019, or around 9\% of GDP, providing around 3.8 million jobs (GSMA, 2020b). Most of this contribution came in the form of increased productivity enabled by mobile technology. The World Bank has estimated the GVA of the ICT sector in nine African economies as part of its Digital Economy for Africa Initiative (see

Table 5); whilst the data for these countries are not all for the same year, the mean contribution to GDP was $4.5 \%$, similar to the Google \& the IFC's (2020) iGDP-based estimate for the region. 
Table 5: ICT sector GVA and contribution to GDP.

\begin{tabular}{lll}
\hline Country (year) & $\$$ & $\%$ GDP \\
\hline Cameroon (2016) & $\$ 1.6$ billion & $5.0 \%$ \\
\hline Nigeria (2017) & $\$ 31$ billion & $7.7 \%$ \\
\hline Tunisia (2017) & $\$ 1.73$ billion & $4.3 \%$ \\
\hline Ghana (2017) & $\$ 17$ billion & $3.6 \%$ \\
\hline Kenya (2017) & $\$ 5.5$ billion & $7.0 \%$ \\
\hline Senegal (2016) & $\$ 0.76$ billion & $4.0 \%$ \\
\hline Zambia (2018) & $\$ 1.19$ billion & $4.4 \%$ \\
\hline South Africa (2017) & $\$ 10.5$ billion & $3.0 \%$ \\
\hline Rwanda (2019) & $\$ 0.14$ billion & $1.4 \%$ \\
\hline
\end{tabular}

Source: World Bank (2019b-e, 2020b-e), licensed under CC BY-NC-SA 3.0

Africa's digital economy has been growing rapidly and this is expected to continue. iGDP as a proportion of Africa's GDP has likely more than tripled since 2012, when McKinsey estimated that the iGDP of Africa's fourteen largest economies was just $\$ 17.7$ billion, or $1.1 \%$ of their cumulative GDP (Manyika et al. 2013). The World Bank's consistent methodology confirms that there has been strong growth in the region's digital economy in recent years. For example, Cameroon's digital economy grew from 1.4\% of GDP in 2000 to 5\% in 2016 (Word Bank, 2020b), whilst Nigeria's ICT GVA rose from 6\% to 12.2\% of GDP between 2010 and 2018 (World Bank, 2019d).

The growth of Africa's digital economy is expected to remain healthy. Google and the IFC (2020) note that whilst the IMF forecast that Africa's GDP will contract by $3.2 \%$ in 2020 , the region's internet economy has proven "broadly resilient" to the COVID-19 pandemic; even accounting for COVID-19 they forecast that Africa's iGDP will grow 15\% year-on-year in 2020 (to contribute around $\$ 115$ billion of GVA or $4.5 \%$ of the region's GDP). The same research forecasts that Africa's iGDP will rise to $\$ 180$ billion or $5.2 \%$ of GDP by 2025 and as high as $8.5 \%$ of GDP by 2050. Similarly, GSMA forecasts that the contribution of Africa's 'mobile ecosystem' to GDP will rise to $\$ 184$ billion by 2025 , an increase of $19 \%$ relative to 2019 (GSMA, 2020b).

e-commerce remains very under-developed across most of Africa. In 2020 the Middle East and Africa combined were responsible for less than $\$ 42$ billion of e-commerce sales, around $1 \%$ of $\$ 3.9$ trillion of global e-commerce sales (eMarketer.com, 2020). The Global Findex Database (World Bank, 2017) shows that in most countries in Sub-Saharan African less than $4 \%$ of the population bought a product online in 2017. In at least six it was only around $1 \%$ of the population (Liberia, Madagascar, Mauritania, Niger, Rwanda and Sierra Leone), though it rose to as high as $8 \%$ in South Africa, 9\% in Kenya, 12\% in Namibia and 14\% in Mauritius. In 2013 ecommerce represented just $0.43 \%$ of Nigeria's retail sector, $0.38 \%$ of South Africa's retail sector, 
$0.74 \%$ of Angola's retail sector and $0.35 \%$ of Kenya's retail sector (Deloitte, 2015). e-commerce penetration has been rising rapidly, but remains marginal in global terms.

The sector has been growing rapidly in Africa, but it remains an e-commerce backwater in global terms. The Middle East and Africa's share of global e-commerce sales is lower than it was in 2013 (Ducass \& Kwadjane, 2015). This reflects the fact that a decade of "incredible growth" in African e-commerce (Google \& IFC, 2020) has still been slower than that seen in other regions. For example, in 2018, e-commerce market penetration in South Africa reached 1.4\% (Goldstruck et al., 2018), which is over three times the 2013 level. Recent years have seen increasingly strong investment in African e-commerce, though the 30 deals which together raised $\$ 139$ million in 2019 again pales in comparison to that seen in other regions (Google \& IFC, 2020).

\section{What are the implications of the digital economy for services trade?}

In 2018, digitally deliverable service exports were valued at $\mathbf{\$ 2 . 9}$ trillion globally, representing $50 \%$ of all services trade (UNCTAD, 2019c).

However, except for India and China, most of the trade in digitally deliverable services is between advanced economies. Based on the author's analysis of UNCTAD data from 2019 for 109 countries, there is a statistically significant relationship between GDP per capita and trade in ICT services as a percentage of GDP, with every $\$ 10,000$ increase in GDP per capita being associated with a 0.7 percentage point increase in trade in ICT services as a percentage of GDP. US international trade in ICT services and ICT-enabled services is dominated by trade with Europe and Asia (almost all China and India).

However, digitally deliverable service exports are growing for many developing countries, albeit from a low base. The US received only $\$ 184$ million of ICT services imports from Africa in 2018 , compared to around $\$ 19$ billion from Asia. However, it received more than $\$ 3$ billion in ICTenabled services imports from Africa and around $\$ 90$ billion of ICT-enabled services imports from Latin America (there is no available data for Asia) (BEA, 2020). Between 2006 and 2016 Sri Lanka's ICT service sector exports rose from $\$ 166$ million to $\$ 900$ million (de Zylva \& Wignaraja).

Opportunities related to digital services trade could play an important role in spurring growth and providing jobs opportunities in developing countries. Notably, this includes digitally-enabled offshore work under the category of Global Business Services (GBS). This encompasses work such as call centre operations; coding; ICT services; finance, accounting and legal support. India and the Philippines have been described as the developing countries that have achieved the greatest successes in developing the GBS sector (Melia, 2020). 50,000 South Africans already conduct offshore GBS work and employment in the sector has been growing by around $24 \%$ per annum. Estimates developed by South Africa in the Digital Age suggest that it is plausible that this number will reach 150,000 by 2023 and 500,000 by 2030 (Genesis Analytics, 2020).

Cross-border e-commerce is growing rapidly. Cross-border e-commerce was estimated to be worth $\$ 780$ billion in 2019 (Facts \& Factors, 2020), having grown from around $\$ 412$ billion in 
2017 (UNCTAD, 2019c). This offers a potential opportunity for developing countries to increase exports and access global value chains (Sedik et al., 2019).

The global trade in 'electronic transmissions' is also growing rapidly. Electronic transmissions relate to the sale across borders of digital products that do not involve any transfer of physical goods. They are covered by a WTO tariff moratorium, and there have been proposals on making this arrangement permanent (WTO, 2019). In 2011 just $7 \%$ of potentially 'digitizable' products traded internationally took the form of electronic transmissions, but by 2017 this had risen to $55 \%$ or $\$ 139$ billion (Banga, 2019). This trend look set to continue. This represents a shift from goods trade towards services trade, but it could also lead to a reduction in export opportunities for developing countries. For example, in 2017 Malaysia has over \$3 billion and China has over $\$ 15$ billion of net exports for physical digitizable products (Banga, 2019). A proportion of this will relate to products for which the intellectual property resides elsewhere; as a result, they may lose out as trade shifts towards electronic transmissions.

The increasing maturity of 3D printing represents an important next step in the digitalisation of the global economy and could lead to a long-term reduction in goods trade. Banga (2019) reports that 3D printing has grown 22\% per annum over the period 2014-18. Based on the current upwards trend of investment in 3D printing $50 \%$ of manufactured goods will be 'printed' by 2060 , which could eliminate $40 \%$ of international goods trade. The consequences of this for developing countries are unclear, but there are reasons for concern that this could impede traditional export-driven manufacturing paths to prosperity. This risk makes efforts to help developing countries harness new opportunities in the digital economy even more important.

\section{What explains variation in the size of the digital economy between regions and countries?}

The development of the digital economy is inevitably constrained if a high proportion of the population is not able to engage meaningfully in the digital economy as workers or consumers of digital products. Global internet user penetration was $53 \%$ in 2019 . However, as can be seen from Figure 4, below, huge global disparities remain in internet usage, with penetration averaging just $19 \%$ in the world's least developed countries. This is underpinned by: (1) continued issues of availability of quality internet in large parts of many of the world's least developed countries; (2) the high cost of both digital hardware and internet subscriptions relative to incomes in many developing countries (for example, in Africa the average cost of a monthly broadband subscription was $\$ 33$ per month in 2019, higher than in Europe); and (3) issues related to literacy and basic digital skills (ITU \& UNESCO, 2020). 


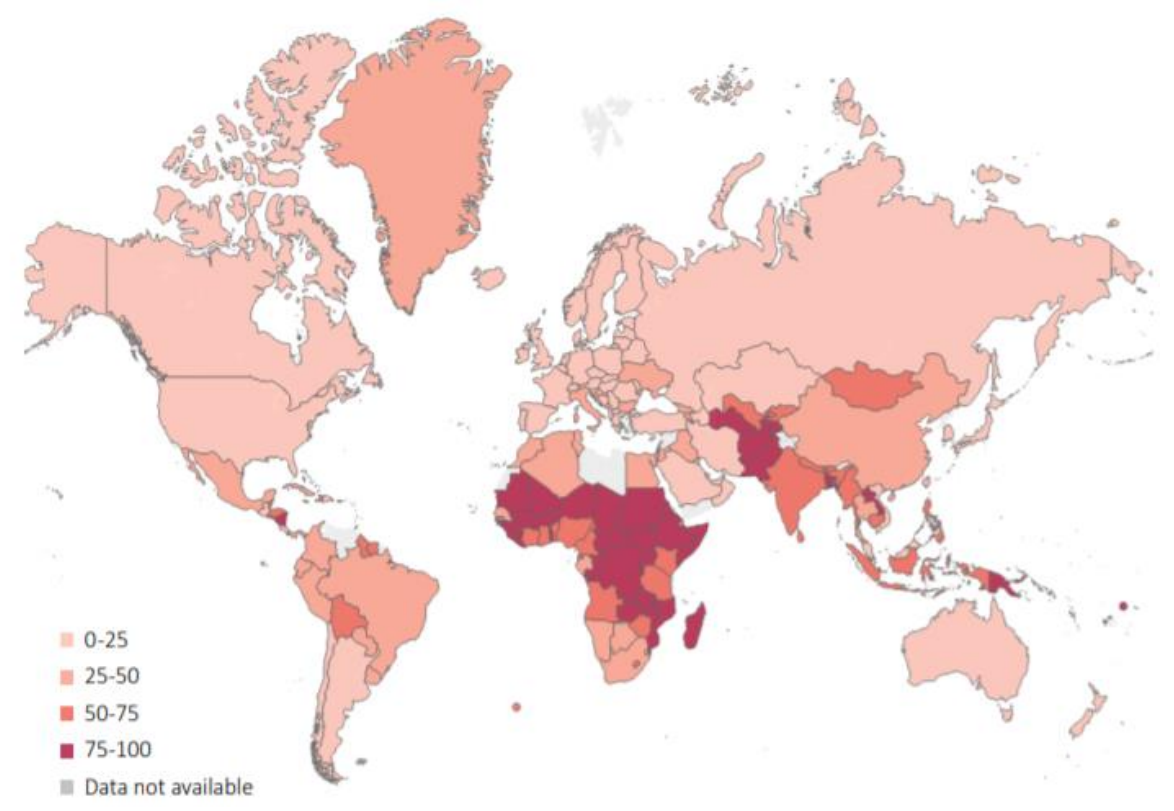

Source: ITU \& UNESCO (2020), licensed under CC BY-NC-SA 3.0

Whilst internet access has been improving almost everywhere the rate of expansion has not been even. In 2020 the proportion of households in middle-income countries with access to the internet grew $12 \%$, whilst in low-income countries, it grew by just $3.8 \%$ (to $9.9 \%$ of households), whilst in lower (ITU \& UNESCO, 2020). The discrepancy in access is evident even for mobile broadband services; there were just 34 mobile broadband subscription for every 100 Africans in 2019, compared to 67 in the Arab States and 89 in Asia and the Pacific and around 100 for Europe and the Americas (ITU \& UNESCO, 2020). Variation is evident even within regions: 4G penetration in Bangladesh lags far behind that elsewhere in the Asia Pacific region (GSMA, 2020). Similarly, the Philippines has around four times as many people per mobile phone tower as does Vietnam, contributing to the former's patchy mobile data coverage; the Philippines relatively weak connectivity - including poor broadband penetration and relatively slow and expensive mobile data access - has been highlighted as a factor underpinning weak digital economy growth there (World Bank, 2020).

Even where businesses and consumers are able to access the internet, there are stark differences between regions in the quality of internet connections. In general, download speeds are high in Europe, North America and parts of Asia Pacific, and slow in Latin America, the Middle East and especially Sub-Saharan Africa (see See: Figure 5). Similarly, the consistency of $4 G$ signals varies a lot between countries, which is a major issue given the much greater reliance on mobile internet in poorer countries. These discrepancies may get starker in the short term as advanced economies and middle-income countries transition towards 5G; unsurprisingly, Sub-Saharan Africa lags behind the rest of the world in the early stages of $5 G$ adoption, with only 18 out of the current 17,056 5G commercially available deployments in Africa (16 in South Africa and 2 in Madagascar), according to speedtest.net. The high cost of 5G infrastructure adoption means that the world's poorest countries will likely lag behind the rest of the world in realising the expected $\$ 13.2$ trillion of additional GVA expected to accrue from $5 \mathrm{G}$ by 2035 (WEF \& PWC, 2020). 
See: Figure 5: Mean download speeds (Mbps between countries compared. Source: Boyland (2019), p.5, https://www.opensignal.com/sites/opensignal-com/files/data/reports/global/data2019-05/the_state_of_mobile_experience_may_2019_0.pdf

See: Figure 6: Consistency of access to 4G compared between countries. Source: Boyland (2019), p.11, https://www.opensignal.com/sites/opensignal-com/files/data/reports/global/data2019-05/the_state_of_mobile_experience_may_2019_0.pdf

The ability of some developing countries to fully exploit the potential of the digital economy is also hampered by literacy and skills issues. Almost $70 \%$ of people in advanced economies have basic ICT skills, compared to $40 \%$ in developing countries and only slightly more than $20 \%$ in the least developed countries (ITU \& UNESCO, 2020). In the least developed countries basic IT skills deficiencies are likely compounded by underlying literacy issues; the problem, therefore, may not as easily resolve itself through users learning from experience as has tended to be the case in the developed world and most middle-income countries.

Many developing countries also have a severe shortage of higher-level technical skills essential to the development of many of the higher value-added elements of the digital economy. The proportion of the workforce with advanced digital skills (e.g. the ability to write computer programmes) is around $7 \%$ in advanced economies, but only around $2 \%$ in developing countries and perhaps 1\% in the least developed countries (ITU, 2020). In 2019 just $2.5 \%$ of the world's professional software developers were in Africa and just 9\% in Latin America (Evans Data Corporation, 2019; Google \& IFC, 2019).

Broader business climate issues are also likely impacting on the development of the digital economy in some developing countries. The usual business climate issues that hamper firm creation, competition and business innovation also affect the growth of the digital economy, sometimes even more so than for the traditional economy. An unconducive environment for start-ups and for foreign investment are both potentially particularly problematic. If it is difficult for new firms to register, secure financing and to operate then a key source of innovation and digital adoption will be undermined. For example, in the Philippines just 300 new firms were created in 2018 per 1 million working-age people, reflecting overly complex procedures for business registration and related bureaucratic issues that affect the viability of new firms, such as the need to secure a complex range of licences and permits (World Bank, 2020). This likely contributes to the under-development of the Philippines' digital economy compared to much of the rest of the Southeast Asian region. Similarly, restrictions on FDI can hamper digital economy development by preventing the inflow of needed funds to kickstart new businesses, as well as the inflow of digital know-how and skills.

Access to climate issues has been identified as a critical factor undermining the development of the digital economy in Africa and other parts of the developing world (Google \& IFC, 2020). In 2019 82\% of African start-ups reported difficulties accessing financing (Google \& IFC, 2020), and this is likely to have become yet more challenging in the wake of the COVID-19 epidemic. Digitally orientated businesses sometimes face particular challenges securing the finance they require because they generally poor in the kind of physical collateral often demanded by conservative lending institutions. 
The growth of e-commerce in some developing countries has been hampered by logistics sector weaknesses. A thriving e-commerce sector requires a reliable and cost-effective logistics sector, in order to ensure that customers receive the goods they pay for in a timely fashion and adequate condition. This remains problematic in many developing countries. For example, the World Bank (2020) highlights that despite an "explosion" of last-mile logistics options in the Philippines in the past decade, logistics costs still remain very high and reliability is poor. This is partly attributable to the de facto closure of the logistics sector to foreign investment, which limits competition and innovation.

\title{
7. What are developing countries doing to promote digital economy growth?
}

\author{
Numerous developing countries have \\ drafted strategies or set-up \\ institutions focused on fostering the \\ development of the digital economy. \\ By 2020174 countries worldwide had \\ some form of national plan to promote \\ the development of their broadband \\ network (ITU \& UNESCO, 2020). Many \\ governments also have more \\ comprehensive plans related to the \\ development of the digital economy or \\ have digital economy-related targets \\ within long-term strategic plans (see \\ Box). The sub-sections below set out \\ some of the specific policies and \\ investments developing country \\ governments are pursuing to develop \\ their digital economies.
}

Many developing countries have plans to promote the growth of the digital

The Indian Government launched the Digital India Program in 2015 to transform India into a "digitally powered society and knowledge economy (Government of India, 2018). The Government of Bangladesh's Vision 2021 includes "Digital Bangladesh" which aims to achieve "socioeconomic transformation through information and ICT " (Rogers, 2020). Sri Lanka is also implementing a Digital Economy Strategy.

The Malaysian Government is preparing a Digital Economy Policy. It already set up the Malaysia Digital Economy Corporation, has National eCommerce Roadmap in place, and is preparing a Digital Economy policy. In Thai Government's Ministry of Digital Economy and Society oversees a Digital Economy Promotion Agency (World Bank, 2020). The Philippines Inclusive Innovation Industrial Strategy has a strong digital focus, and it is in the process of developing an e-commerce roadmap.
South Africa's Government has an e- strategy, which includes seizing the opportunities of the 'digital industrial revolution' as one pillar, in 2020 Kenya's Government released a draft version of its Digital Economy Strategy for consultation, whilst Nigeria has a National Digital Economy Policy and Strategy (2020-2030).

\section{Trade Policies}

The World Trade Organisation's (WTO's) Information Technology Agreement (ITA) is a 1997 treaty that aims to eliminate barriers to trade for ICT-related products. The ITA's 81 signatories are committed to abolishing tariffs on many high technology products including "computers, telecommunication equipment, semiconductors, semiconductor manufacturing and 
testing equipment, software, scientific instruments, as well as most of the parts and accessories of these products" (WTO, 2020).

Following several years of negotiations in 2015 around 50 countries agreed to expand the scope of the agreement to include an additional 201 products which had been invented or become increasingly important since 1997. Together these new product lines account for $\$ 1.3$ trillion of annual trade ( $7 \%$ of global trade). Most advanced economies and many developing economies in East, Southeast and South Asia are signatories to the agreement. In contrast, take-up has been very limited in Africa and Latin America and patchy in the Middle East.

\section{Various regional agreements have also attempted to reduce barriers and ensure a} harmonised approach to digital businesses. In 2018 ASEAN finalised an agreement on ecommerce; whilst it was largely focused on cooperation and higher-level principles, it remains an important starting point towards the development of a common approach in the region (ASEAN, 2019). In recent years East Africa's COMESA free trade area has been developing schemes to facilitate cross-border e-commerce including "an electronic certificate of origin (of goods for export) and a digital free trade area application that will incorporate e-commerce, e-legislation and e-logistics are also being developed" (COMESA, 2018). In February 2020 the African Union Heads of State and Government Assembly agreed to make a "Protocol on E-Commerce" the focus of the Phase 3 Negotiations (likely starting 2021) for the African Continental Free Trade Area (AfCFTA) (African Union, 2020).

\section{Several developing country governments have entered into bilateral free trade} agreements with advanced economies which include aspects of digital trade. E-commerce is included in Morocco's free trade agreement with the USA and in 2020 Kenya's Ministry of Trade stated that it was looking to include e-commerce within a potential Kenya-USA free trade agreement (Business Daily Africa, 2020). E-commerce measures are also included in the 2006 Thailand-Australia free trade agreement, in the EU's 2008 free trade agreement with the CARIFORUM Caribbean states (Ikigai Law, 2020).

\section{Incentive schemes}

Many middle-income countries use R\&D subsidies in pursuit of their industrial strategies, much of which likely supports research relevant to the development of the digital economy. Governments in many countries provide incentives to encourage Business Enterprise Research \& Development (BERD) (i.e. R\&D activity by the private sector). Whilst this does not exclusively relate to the digital economy, a fairly high proportion of BERD spending has related to ICT and digital innovation. The extent of government support varies a huge amount across the G20, as can be seen from See: Figure7 below. Every G20 country provides some direct funding to BERD (ITU, 2018), with most providing less than $0.1 \%$ of GDP in direct funding and Russia standing out with its much larger $0.4 \%$ of GDP direct contribution. In contrast, tax incentives for BERD vary quite widely - with France providing the most generous support valued at slightly less than $0.3 \%$ of GDP, but Germany, Mexico and Argentina providing no support at all. Based on the G20 data, there is no clear relationship between national size or wealth and government support to BERD, with both the highest spender (relative to GDP) and three lowest spenders being middle-income countries.

Various developing country governments have grant schemes focused on encouraging digital sector start-ups. The Indian Government funds a variety of grant schemes including the 
PRISM Technopreneur Promotion Program (TePP) provides up to $\$ 140,000$ to help start-ups realise particularly innovative ideas and the Multiplier Grants Scheme (MGS) specifically for technology start-ups (Padhiar, 2018). Malaysia's Government provides a 50\% matching grant scheme for SMEs to "adopt digitalisation in daily operations." (Government of Malaysia, 2020). Grant schemes focused on the development of the digital economy appear relatively rare in SubSaharan Africa and offer very limited funding when they do exist. For example, Nigeria's Ministry of Communications and Digital Economy announced a grant scheme in 2020 for SMEs offering innovative solutions to the challenges posed by COVID-19, but its first funding round made just three awards, with the largest being for $\$ 2,600$ (Udoh, 2020).

See: Figure 7: Direct government funding of business $R \& D$ and tax incentives for $R \& D$ as a percentage of GDP across G20 countries, 2015. Source: ITU (2018), p.43, utilising OECD data. https://www.itu.int/en/ITU-D/Statistics/Documents/g20-detf-toolkit_FINAL.pdf

\section{Improving network access}

Government action over the past decade to expand and improve internet access has played an important role in laying the foundations for the growth of the digital economy in many developing countries. In 2010 Africa's international internet bandwidth was ten times what it was in 2010. This reflects a massive increase in undersea fibre optic cables connecting Africa to the rest of the world and a huge increase in the terrestrial fibre optic network. Over the 2010 s Africa's terrestrial network grew by $12.5 \%$ per annum and "last-mile fibre network" grew at a rate of $96 \%$ per annum between 2016 and 2019 (Google \& IFC, 2020). Whilst the expansion of undersea cables is partly the result of direct investments by multinational tech companies (Google \& IFC, 2020), the expansion of the terrestrial network has often been led by developing country governments.

Developing country governments have directly invested in expanded telecommunications networks or utilised PPPs to harness private sector financing to improve internet access. Government involvement may include direct involvement in constructing telecommunications infrastructure, notably through state-owned enterprises and PPPs. For example, in the 2010s saw state-owned Maroc Telecom invest $\$ 1.2$ billion investment to "upgrade its network and install fibre optics across Morocco". The Philippines is deploying its own fibre optic network in the Manilla Metropolitan Area and a 'national broadband plan' has been developed to expand broadband access nationwide (though with uncertainty whether the government will opt for direct provision or a market-based approach) (World Bank, 2020). The governments of Mexico and Rwanda have attempted to improve broadband access through Shared Network Infrastructure (SNI) projects, with South Africa in the process of implementing a similar initiative. The SNI concept is based on a "wholesale network providing capacity [exclusively] to the commercial operators that serve end users" (World Bank, 2018).

Various less conventional schemes have been attempted to expand access to the internet to under-served communities. For example, in 2015 the Philippines the government developed a Free Public Wi-Fi program "intended to provide internet service to low-income locations" (World Bank, 2020). In Cameroon, in 2016 the President offered free laptop to all university students in 
the country as a "gift" (P.R.C, 2016). In practice these schemes have often proved controversial: Cameroon's scheme has been plagued by delays, quality issues and allegations of corruption (CamerounWeb.com, 2020), whilst the Philippines scheme has only generated $3 \%$ of its target for free WiFi sites.

\section{Digital economy regulation}

One key area that governments can take to enable the digital economy is to update and future proof regulatory frameworks in order to avoid impeding the growth of the online sector. Regulatory decisions are crucial to expanding internet access given evidence that broadband adoption is highly sensitive to price; data from Latin America suggests that a $10 \%$ drop in prices may boost adoption by more than 3\% (ITU, 2019). The World Bank (2020) suggests that the Philippines poor connectivity is partly the result of an "outdated" Radio Control Law and "the lack of an open-access policy."

The regulatory implications of the digital economy are varied, complex and sometimes contentious. Key regulatory issues include employment - notably the legal status of 'gig economy' jobs enabled by digital technology (Genesis Analytics) - data privacy and ownership, and competition regulations. The debate on the regulation of the digital economy has not yet reached full maturity, and whilst there are those arguing that developing countries need lighttouch regulation in order to support the growth of the digital economy (Paine, 2020), there are also voices calling for strong regulatory oversight of the digital private sector in order to prevent the emergence of ever more extreme "surveillance capitalism" (Zuboff, 2019) in which the interests of society and the individual are marginalised. This argument has already begun playing out in Southeast Asia regarding regulatory restrictions on cross-border data flows, which some regard as vital for privacy whilst others worry will hamper the growth of the digital economy (Paine, 2020).

Tech-savvy developing countries have already begun adopting regulatory changes designed to support the growth of the digital economy, but many more have yet to fully get to grips with the changes required. The World Bank's Digital Economy for Africa Initiative has conducted diagnostic reports for 11 African economies, including an assessment of the state of their regulatory environment for digitally orientated businesses. As can be seen from Figure8, below, four of these countries only had the "barebones" of a regulatory framework, with another five requiring "major additions or amendments." In Southeast Asia several governments including Vietnam, Indonesia, Cambodia, Thailand and the Philippines - have recently introduced new content regulations and licensing requirements, though some detractors have suggested that the net effect of new regulations has been to increase the onerousness of regulations on the private sector, potentially hampering the growth of the digital economy (Paine, 2020). 
Figure 8: World Bank Digital Economy for Africa Initiative diagnosis of the state of the regulatory environment facing digitally orientated businesses in 11 African economies.

\begin{tabular}{|c|c|c|c|c|c|}
\hline Country & $\begin{array}{l}\text { No substantial } \\
\text { regulation }\end{array}$ & $\begin{array}{l}\text { Only barebones } \\
\text { framework or } \\
\text { dispersed } \\
\text { individual } \\
\text { regulation }\end{array}$ & $\begin{array}{l}\text { Comprehensive } \\
\text { regulatory } \\
\text { framework, but } \\
\text { with major } \\
\text { additions or } \\
\text { amendments } \\
\text { needed }\end{array}$ & $\begin{array}{l}\text { Comprehensive } \\
\text { regulation in place, } \\
\text { but small additions } \\
\text { or upgrades } \\
\text { recommended }\end{array}$ & $\begin{array}{l}\text { Comprehensive } \\
\text { and modern } \\
\text { regulation in } \\
\text { place }\end{array}$ \\
\hline Cameroon & $x$ & ( & $x$ & $x$ & $x$ \\
\hline Gabon & (x) & 2 & (x) & 8 & (x) \\
\hline Ghana & (x) & $x$ & 2 & $x$ & $x$ \\
\hline Kenya & $x$ & (x) & (x) & 2 & 8 \\
\hline Madagascar & $x$ & ( & $x$ & $x$ & $x$ \\
\hline Mozambique & (x) & $x$ & ( & (x) & 8 \\
\hline Nigeria & (x) & $x$ & 2 & 8 & $x$ \\
\hline Rwanda & (x) & 8 & $\checkmark$ & 8 & X) \\
\hline Senegal & (x) & 2 & $x$ & $x$ & $x$ \\
\hline Seychelles & $x$ & $x$ & 2 & (x) & $x$ \\
\hline South Africa & $x$ & $x$ & $x$ & ㄱ. & $x$ \\
\hline
\end{tabular}

Source: Google and IFC, a member of the World Bank Group (2020), p.75

Financial sector regulatory reforms to facilitate e-payments are critical enablers of the development of the digital economy. The World Bank (2020) has highlighted the weakness of e-payment systems as a factor underpinning the Philippines relative underperformance in developing its e-commerce sector. Since 2017 the government there has been developing the regulatory framework and retail payment infrastructure to enable modernised e-payments, though gaps remain in relation to electronic payments, including the lack of an adequate system to enable direct debit payments. In 2018 Thailand launched a government-backed electronic money transfer service that forced banks to waive fees for retail e-transactions (Sedik et al., 2019). 


\section{Improving digital skills}

Developing country governments have increasingly recognised that they will need to invest in building the digital skills of their workforce. For example, the South African Government's South Africa in the Digital Age (SADA) process has recommended a focus on improving engineering and computer science faculties in universities. Several African Governments, notably Uganda and Rwanda, have been increasing investment in university-level STEM education in order to address skills shortages needed to develop their digital economies (Google \& IFC, 2019).

In the Philippines, the Department of Education is working to integrate ICT skills into the school curriculum under the "Digital Rise Program" (World Bank, 2020a), whilst in Rwanda, the Government now provides scholarships to high school students taking STEM subjects (Google \& IFC, 2019). In the short-term, various developing countries have considered or are implementing special visa and immigration arrangements designed to ensure an adequate supply of highskilled workers needed to support the development of the digital economy (Mutula and Brakel, 2007; Genesis Analytics, 2020).
Connect, Harness, Innovate and

\section{Protect (CHIP)}

CHIP is a conceptual framework used by, amongst others, the World Bank (2020) to analyse the requirements to accelerate the development of the digital economy. It sets out four drivers of digitalisation:

- Connect: measures to build the digital foundation and enablers such as digital infrastructure for participation in the digital economy

- Harness: complementary noninfrastructure investments (e.g. in skills, regulations, and institutions)

- Innovate: expanding new economy services, digital payments, digital entrepreneurship and e-government

- Protect: mitigating risks from the digital economy.

\section{Other measures}

The supporting environment for digital entrepreneurship has been improving in many developing countries, with increasing numbers of 'hubs' and 'accelerator programmes' to support technology-orientated businesses. By 2019 there were 643 hubs and 90 active accelerators in Africa (Google \& IFC, 2020). Most hubs and accelerators in developing countries are run as standalone businesses, some are created by technology sector multinationals and some have been established through donor-funded programmes.

Fostering digital demand by developing e-government. Some developing country governments have adopted a deliberate policy of fostering digital demand (Genesis Analytics), including through "digital-friendly government procurement" and expansion of e-government services such as "benefit payments, tax filing, and passport applications online" (Manyika et al., 2013). The UN's e-government Development Index (UN, 2020) reveals that, unsurprisingly, developing countries lag behind advanced economies on e-government development. Latin American countries and several countries in Southeast Asia appear to have developed relatively strong e-government systems, whilst Sub-Saharan Africa (with the exception of South Africa and Ghana) and (with a few clear exceptions) the Middle East and North Africa lagging far behind. 
See: Figure 9: UN E-Government Development Index.

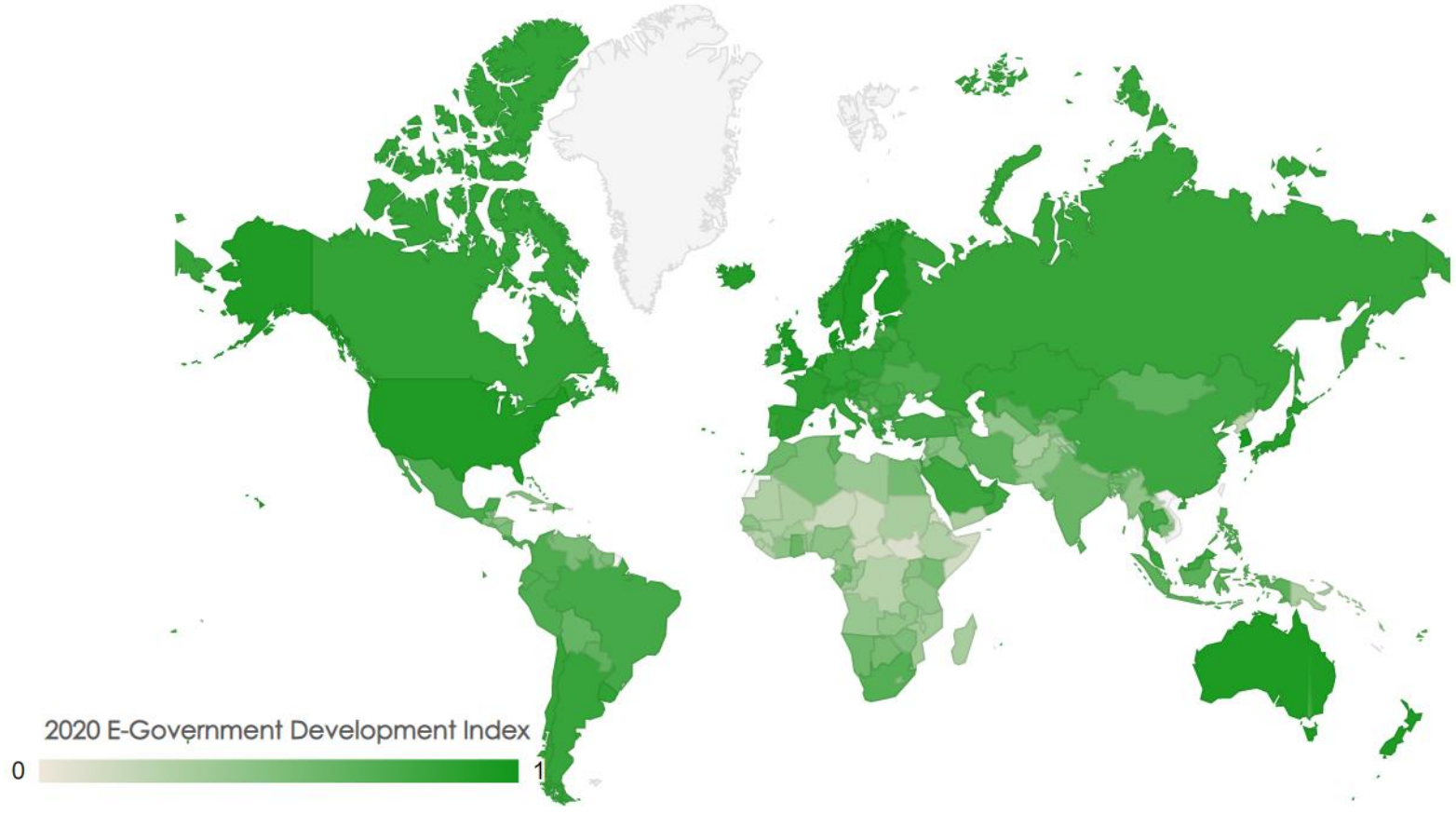

Source: United Nations: https://publicadministration.un.org/egovkb/en-us/Data/Compare-Countries 


\section{References}

Accenture (2018) El avance de la economía digital en chile.

https://www.accenture.com/t00010101t000000z_w__cl-es/_acnmedia/pdf-71/accenture-digitalindex-chile.pdf

African Union (2020). Decision on the African Continental Free Trade Area (AfCFTA) Doc.

Assembly/AU/4(XXXIII). https://www.tralac.org/documents/resources/cfta/3176-au-assembly-decisionon-the-afcfta-february-2020/file.html

Armstrong, B. (2020) The digital economy is becoming ordinary. Best we understand it. The Conversation. https://theconversation.com/the-digital-economy-is-becoming-ordinary-best-weunderstand-it-

130398\#: :text=The\%20digital\%20economy\%20is\%20a,the\%20internet\%20on\%20the\%20economy.

ASEAN (2019) ASEAN agreement on electronic commerce.

https://static1.squarespace.com/static/5393d501e4b0643446abd228/t/5c99e02aeef1a10aa126c9a6/1 553588313303/20190306035048.pdf

Bain and Co. (2019) E-commerce in the MENA region: Opportunity beyond the hype.

https://www.bain.com/contentassets/2b078686303045ffa1d1207130ab5d79/bain_report_ecommerc e_in_mena.pdf

Banga, R. (2019) Growing Trade in Electronic Transmissions: Implications for the South. https://unctad.org/system/files/official-document/ser-rp-2019d1_en.pdf

Barefoot, K., Curtis, D., Jolliff, W., Nicholson, J. R., \& Omohundro, R. (2018). Defining and measuring the digital economy. US Department of Commerce Bureau of Economic Analysis.

https://www.bea.gov/sites/default/files/papers/defining-and-measuring-the-digital-economy.pdf

Boyland, P. (2019). The State of Mobile Network Experience: Benchmarking mobile on the eve of the $5 G$ revolution. London: Opensignal. https:/www.opensignal.com/sites/opensignalcom/files/data/reports/global/data-2019-05/the_state_of_mobile_experience_may_2019_0.pdf

Business Daily Africa (2020) Kenya eyes e-commerce investments in US pact. Accessed 30/11/2020: https://www.businessdailyafrica.com/bd/economy/kenya-eyes-e-commerce-investments-in-us-pact2294248

CamerounWeb.com (2020) Un étudiant un ordinateur : ce projet de Paul Biya qui ne valait pas la peine. https://www.camerounweb.com/CameroonHomePage/NewsArchive/Un-tudiant-un-ordinateurce-projet-de-Paul-Biya-qui-ne-valait-pas-la-peine-484600

COMESA (2018) COMESA leaps into digital integrated regional economy

http://www.comesaria.org/news/comesa-leaps-into-digital-integrated-regional-economy.53973.64.html

Deloitte (2015) African Powers of Retailing New horizons for growth

https://www2.deloitte.com/content/dam/Deloitte/ng/Documents/consumer-business/ng-africanpowers-of-retailing-new-horizons-for-growth.pdf

Ducass, A., \& Kwadjane, J-M. (2015) E-commerce in Africa: Morocco, Tunisia, Senegal and Ivory Coast. http://www.ipemed.coop/admin/pemed/media/fich_article/1461745665_ipemedrapportecommerce-en-afrique-enbd.pdf 
Economist Intelligence Unit (2018) The 2018 Government e-payments adoption ranking. https://usa.visa.com/content/dam/VCOM/global/visa-everywhere/documents/government-e-paymentadoption-ranking-study-2018.pdf

Elmasry, T., Benni, E., Patel, J., \& Moore, J. P. (2016). Digital Middle East: Transforming the region into a leading digital economy. New York: Mckinsey \& Company.:

https://www.mckinsey.com/ /media/mckinsey/featured\%20insights/middle\%20east\%20and\%20africa/ digital\%20middle\%20east\%20transforming\%20the\%20region\%20into\%20a\%20leading\%20digital\%2 0economy/digital-middle-east-final-updated.pdf

eMarketer.com (2020) Global Ecommerce 2020. https://www.emarketer.com/content/globalecommerce-2020\#page-report

eMarketer.com (2020b) China Ecommerce 2020. https://www.emarketer.com/content/chinaecommerce-2020

eMarketer.com (2020b) Latin America Ecommerce 2020. https://www.emarketer.com/content/latinamerica-ecommerce-2020

Eurostat. (2020a). ICT sector - value added, employment and R\&D. Luxembourg: Eurostat. https://ec.europa.eu/eurostat/statistics-explained/index.php/ICT_sector__value_added,_employment_and_R\%26D\#The_size_of_the_ICT_sector_as_measured_by_value_ad ded

Evans Data Corporation (2019) Worldwide Developer Population and Demographic Study 2020. https://evansdata.com/press/viewRelease. php?pressID=278

Facts \& Factors (2020) Cross-Border B2C E-Commerce Market. https://www.fnfresearch.com/crossborder-b2c-e-commerce-market-by-category-852

Genesis Analytics (2020) Pathways to Digital Work: A Strategy Primer for South Africa's Digital Economy. https://www.genesis-analytics.com/uploads/Pathways-to-Digital-Work-SADA-StrategyPrimer-full-report.pdf

Goldstruck, A., \& Elliott, B. (2018) Online Retail in South Africa 2019. World Wide Worx. http://www.worldwideworx.com/wp-content/uploads/2018/12/Exec-Summary-Online-Retail-in-SA2019.pdf

Google \& the IFC, e-Conomy Africa 2020.

https://kstatic.googleusercontent.com/files/ad1166fd6e3289b5e6445c73e4cff5bbb9df1927d35cff4f4b5 efa8ebb4fe16620d5ddb499d17956ea850bcac8f6d05faf1c2f1ca7f558bf1296b5303958f334

Google \& Temasek / Bain, e-Conomy SEA 2019.

https://www.blog.google/documents/47/SEA_Internet_Economy_Report_2019.pdf

Government of India (2018) India's trillion-dollar digital opportunity.

https://www.meity.gov.in/writereaddata/files/india_trillion-dollar_digital_opportunity.pdf

Government of Malaysia (2020) SME Digitalisation Grant. https://mdec.my/digital-economyinitiatives/for-the-industry/sme-digitalisation-grant/

GSMA (2019a) The Mobile Economy Latin America 2019. https://www.gsma.com/latinamerica/wpcontent/uploads/2020/02/Mobile-Economy-Latin-America-2019-English-Full-Report.pdf

GSMA (2019b) State of the Industry Report on Mobile Money 2019. https://www.gsma.com/sotir/wpcontent/uploads/2020/03/GSMA-State-of-the-Industry-Report-on-Mobile-Money-2019-Full-Report.pdf 
GSMA (2020a) The Mobile Economy 2020: Asia Pacific. https://www.gsma.com/mobileeconomy/wpcontent/uploads/2020/06/GSMA_MobileEconomy_2020_AsiaPacific.pdf

GSMA (2020b) The Mobile Economy 2020: Sub-Saharan Africa.

https://www.gsma.com/mobileeconomy/wp-

content/uploads/2020/09/GSMA_MobileEconomy2020_SSA_Eng.pdf

Huawei \& Oxford Economics. (2017). Digital Spillover. Measuring the true impact of the Digital

Economy. Shenzen: Huawei. https://www.huawei.com/minisite/gci/en/digital-

spillover/files/gci_digital_spillover.pdf

ICANN. (2017). Accelerating the Digital Economy in the Middle East, North Africa and Turkey. California: The Internet Corporation for Assigned Names and Numbers. https://www.icann.org/en/system/files/files/accelerating-digital-economy-report-09oct17-en.pdf

Ikigai Law (2020) Analysing E-Commerce Norms in Free Trade Agreements: Notes for WTO's Plurilateral Negotiations. https://www.ikigailaw.com/analysing-e-commerce-norms-in-free-tradeagreements-notes-for-wtos-plurilateral-negotiations/\#_ftn7

ITU (2018) Toolkit for measuring the digital economy. https://www.itu.int/en/ITUD/Statistics/Documents/g20-detf-toolkit_FINAL.pdf

ITU (2019) The economic contribution of broadband, digitization and ICT regulation Econometric modelling for the Americas. https://www.itu.int/myitu/-/media/Publications/2020-Publications/EN--Econometric-modelling-for-the-Americas.pdf

ITU \& UNESCO (2020) The State of Broadband: Tackling digital inequalities - a decade for action. https://www.itu.int/dms_pub/itu-s/opb/pol/S-POL-BROADBAND.21-2020-PDF-E.pdf

Kaka, N., Madgavkar, A., Kshirsagar, A., Gupta, R., Manyika, J., Bahl, K., \& Gupta, S. (2019). Digital India: Technology to transform a connected nation. New York: Mckinsey \& Company. Retrived from: https://www.mckinsey.com/ /media/McKinsey/Business\%20Functions/McKinsey\%20Digital/Our\%20In sights/Digital\%20India\%20Technology\%20to\%20transform\%20a\%20connected\%20nation/MGI-

Digital-India-Exec-summary-April-2019.pdf

Knickrehm, M., Berthon, B., \& Daugherty, P. (2016). Digital disruption: The growth multiplier. Dublin: accenture, 1-12. http://www. anupartha.com/wp-content/uploads/2016/01/Accenture-Strategy-DigitalDisruption-Growth-Multiplier.pdf

Leverenz, J., \& Vajpayee, B. (2019) Ride hailing in emerging markets is more than transport. https://www.blog.invesco.us.com/ride-hailing-in-emerging-markets-is-more-than-transport/

Manyika, J., Cabral, A., Moodley, L., Moraje, S., Yeboah-Amankwah, S., Chui, M., \& Anthonyrajah, J. (2013). Lions go digital: The Internet's transformative potential in Africa. McKinsey \& Company. https://www.mckinsey.com/ /media/McKinsey/Industries/Technology\%20Media\%20and\%20Telecom munications/High\%20Tech/Our\%20Insights/Lions\%20go\%20digital\%20The\%20Internets\%20transfor mative\%20potential\%20in\%20Africa/MGI_Lions_go_digital_Full_report_Nov2013.pdf

Marinova, P. (2017) This Is Only the Beginning for China's Explosive E-Commerce Growth.

Melia, E. (2020) African jobs in the digital era: Export options with a focus on online labour. https://www.econstor.eu/bitstream/10419/214203/1/169088360X.pdf

Mutula, S. M. \& Brakel, P. V. (2007). ICT Skills Readiness for the Emerging Global Digital Economy Among Small Business in Developing Countries: Case Study of Botswana. Library Hi Tech, 25 (2). Retrieved from: https://doi.org/10.1108/07378830710754992 
Nicholson, J. (2020) New Digital Economy Estimates. US Department of Commerce Bureau of Economic Analysis. https://www.bea.gov/system/files/2020-08/New-Digital-Economy-EstimatesAugust-2020.pdf

OECD (2020) A ROADMAP TOWARD A COMMON FRAMEWORK FOR MEASURING THE DIGITAL ECONOMY. http://www.oecd.org/sti/roadmap-toward-a-common-framework-for-measuring-the-digitaleconomy.pdf

Oxford Business Group (2020) New technologies strengthen Morocco's ICT sector. The Report: Morocco 2020. Accessed: 29/11/2020: https://oxfordbusinessgroup.com/overview/speed-push-adoptnew-technologies-strengthens-country\%E2\%80\%99s-position-regional-and-continental-innovator

Padhiar, J. (2018) Top 7 Startup Business Grants In India For Some Easy Money.

https://digest.myhq.in/startup-business-grants-india/

Paine, J. (2020) Digital economy crucial in ASEAN's post-pandemic recovery. The Scoop. Retrieved 23/11/2020 from: https://thescoop.co/2020/11/17/digital-economy-crucial-in-aseans-post-pandemicrecovery/

P.R.C. (2016). Digital economy: A great gift of the Head of State to students. Cameroon: The Presidency of the Republic of Cameroon. Retrived from: https://www.prc.cm/en/news/1870digitaleconomy-a-great-gift-of-the-head-of-state-to-students

Robinson, J. (2020). Pakistan: progressing towards a fully fledged digital economy. London: Global System for Mobile Communications Association. Retrived from: https://www.gsma.com/asia-pacific/wpcontent/uploads/2020/06/24253-Pakistan-report-updates-LR.pdf

Rogers, M. (2018) GSMA Country overview: Bangladesh. https://data.gsmaintelligence.com/apiweb/v2/research-file-download?id=30933394\&file=Country\%20overview\%20Bangladesh.pdf

Singh, J. (2020) Numbers tell the story of Ola vs Uber rivalry in India.

https://entrackr.com/2020/02/uber-ola-market-share-rivalry-in-india/

statista (2020) Retail market size in India 2011-2026. Accessed 28/11/2020:

https://www.statista.com/statistics/935872/india-retail-market-size/

Udoh, C. (2020) Nigeria Approves Research Grants For Startups With Digital Solutions To COVID-19. https://afrikanheroes.com/2020/05/08/nigeria-approves-research-grants-for-startups-with-digitalsolutions-to-covid-19/

UNCTAD (2019a) Digital Economy Report 2019. https://unctad.org/system/files/officialdocument/der2019_en.pdf

UNCTAD (2019b) Measuring domestic and cross-border e-commerce.

https://unctad.org/system/files/non-official-document/tdb_ede_wg2019p05_Minges.pdf

UNCTAD (2019c) UNCTAD B2C E-COMMERCE INDEX 2019

https://unctad.org/en/PublicationsLibrary/tn_unctad_ict4d14_en.pdf

Van Ark, B., \& de Vries, K. (2019) Productivity \& Innovation Competencies in the Midst of the Digital Transformation Age: A EU-US Comparison. https://ec.europa.eu/info/sites/info/files/economyfinance/dp119 en.pdf

World Economic Forum, \& PwC. (2020). The Impact of 5G: Creating New Value across Industries and Society. Geneva: World Economic Forum. Retrived from: https://www.pwc.com/gx/en/aboutpwc/contribution-to-debate/wef-the-impact-of-fiveg-report.pdf 
World Bank (2017) The Global FINDEX database 2017.

https://globalfindex.worldbank.org/\#data_sec_focus

World Bank (2019a). "Information and Communications for Development 2018: Data-Driven Development." Overview booklet. Information and Communications for Development. World Bank, Washington, DC. License: Creative Commons Attribution CC BY 3.0 IGO.

http://documents1.worldbank.org/curated/en/674601544534500678/pdf/Main-Report.pdf

World Bank (2019b) Ghana Digital Economy Diagnostic.

http://pubdocs.worldbank.org/en/412821598381054828/Ghana-DE4A-LOW-Res.pdf

World Bank (2019c) Kenya Digital Economy Assessment.

http://pubdocs.worldbank.org/en/345341601590631958/DE4A-Kenya-summary-paper-final.pdf

World Bank (2019d) Nigeria Digital Economy Diagnostic Report.

https://documents.worldbank.org/en/publication/documents-

reports/documentdetail/387871574812599817/nigeria-digital-economy-diagnostic-report

World Bank (2019e) Country Diagnostic of Senegal (English). Washington, D.C. : World Bank Group. http://documents.worldbank.org/curated/en/814111559645179494/Country-Diagnostic-ofSenegal

World Bank (2019f) South Africa - Digital Economy Diagnostic (English). Washington, D.C. : World Bank Group. http://documents.worldbank.org/curated/en/464421589343923215/SouthAfrica-Digital-Economy-Diagnostic

World Bank. (2020a). Philippines Digital Economy Report 2020: A Better Normal Under COVID-19Digitalizing the Philippine Economy Now.

http://documents1.worldbank.org/curated/en/796871601650398190/pdf/Philippines-Digital-EconomyReport-2020-A-Better-Normal-Under-COVID-19-Digitalizing-the-Philippine-Economy-Now.pdf

World Bank (2020b) Cameroon Digital Economy Assessment: Country Diagnostic.

http://pubdocs.worldbank.org/en/379941605627277587/DE4A-Cameroon-Country-DiagnosticJun-26.pdf

World Bank (2020c). Rwanda Economic Update: January 2020.

https://openknowledge.worldbank.org/bitstream/handle/10986/33247/Rwanda-Economic-UpdateAccelerating-Digital-Transformation-in-Rwanda. pdf? sequence $=1$ \&isAllowed=y

World Bank (2020d). Diagnostic de l'Economie Numerique de la Tunisie (French). Washington, D.C. : World Bank Group.

http://documents.worldbank.org/curated/en/822451592422759317/Diagnostic-de-IEconomieNumerique-de-la-Tunisie

World Bank (2020e). Accelerating Digital Transformation in Zambia: Digital Economy Diagnostic Report. World Bank, Washington, DC. (C) World Bank.

https://openknowledge.worldbank.org/handle/10986/33806

WTO (2019). Joint Statement on Electronic Commerce EU Proposal for WTO Disciplines and Commitments Relating to Electronic Commerce.

http://trade.ec.europa.eu/doclib/docs/2019/may/tradoc_157880.pdf

WTO (2020) Information Technology Agreement — an explanation. Retrieved 23/11/2020:

https://www.wto.org/english/tratop_e/inftec_e/itaintro_e.htm

Zhang, Longmei and Sally Chen, 2019. "China's Digital Economy: Opportunities and Risks". IMF Working Paper. WP/19/16 
Zuboff, S. (2019). The Age of Surveillance Capitalism: The Fight for a Human Future at the New Frontier of Power: Barack Obama's Books of 2019. Profile Books.

\section{Key websites}

- International Monetary Fund Data: https://data.imf.org/

- UNCTAD statistics: https://unctadstat.unctad.org/

- World Bank Open Data: http://data.worldbank.org/

- speedtest.net/

- Statista: https://www.statista.com/

\section{Suggested citation}

Herbert, G. \& Loudon, L. (2020). The size and growth potential of the digital economy in ODAeligible countries. K4D Helpdesk Report. Brighton, UK: Institute of Development Studies. DOI: 10.19088/K4D.2021.016

\section{About this report}

This report is based on six days of desk-based research. The K4D research helpdesk provides rapid syntheses of a selection of recent relevant literature and international expert thinking in response to specific questions relating to international development. For any enquiries, contact helpdesk@k4d.info.

K4D services are provided by a consortium of leading organisations working in international development, led by the Institute of Development Studies (IDS), with Education Development Trust, Itad, University of Leeds Nuffield Centre for International Health and Development, Liverpool School of Tropical Medicine (LSTM), University of Birmingham International Development Department (IDD) and the University of Manchester Humanitarian and Conflict Response Institute (HCRI).

This report was prepared for the UK Government's Foreign, Commonwealth and Development Office (FCDO) and its partners in support of pro-poor programmes. Except where otherwise stated, it is licensed for non-commercial purposes under the terms of the Open Government Licence v3.0. K4D cannot be held responsible for errors, omissions or any consequences arising from the use of information contained in this report. Any views and opinions expressed do not necessarily reflect those of FCDO, K4D or any other contributing organisation.

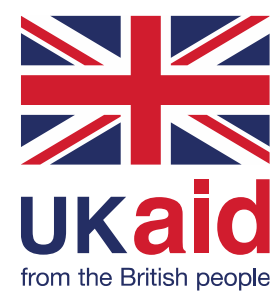

(C) Crown copyright 2020. 